Portland State University

PDXScholar

\title{
Body Size and Condition, Timing of Breeding, and Aspects of Egg Production in Eastern Kingbirds
}

\author{
Michael T. Murphy \\ Portland State University, murphym@pdx.edu
}

Follow this and additional works at: https://pdxscholar.library.pdx.edu/bio_fac

Part of the Biology Commons, and the Ornithology Commons Let us know how access to this document benefits you.

\section{Citation Details}

Murphy, Michael T., "Body Size and Condition, Timing of Breeding, and Aspects of Egg Production in Eastern Kingbirds" (1986). Biology Faculty Publications and Presentations. 81.

https://pdxscholar.library.pdx.edu/bio_fac/81

This Article is brought to you for free and open access. It has been accepted for inclusion in Biology Faculty Publications and Presentations by an authorized administrator of PDXScholar. Please contact us if we can make this document more accessible: pdxscholar@pdx.edu. 


\title{
BODY SIZE AND CONDITION, TIMING OF BREEDING, AND ASPECTS OF EGG PRODUCTION IN EASTERN KINGBIRDS
}

\author{
MICHAEL T. MURPHY ${ }^{1}$ \\ Department of Systematics and Ecology, Museum of Natural History, The University of Kansas, \\ Lawrence, Kansas 66045 USA
}

\begin{abstract}
Variation in timing of breeding in Eastern Kingbirds (Tyrannus tyrannus) was correlated only weakly with external morphological characters, but was correlated positively and significantly with estimates of body size based on measurements of skeletons and muscle weights. Small females apparently held a reproductive advantage in being able to mobilize resources for reproduction before large females. Egg weight was independent of all measures of female size, but was directly and significantly $(P=0.03)$ correlated with standard flight muscle weight, a relative index of body condition. Egg size was thus a function more of female body condition than size.

On average, shell, yolk, and albumen comprised $5.6 \%, 21.9 \%$, and $72.5 \%$, respectively, of fresh egg weight. Dry albumen and dry shell increased proportionately with fresh egg weight, but dry yolk did not. Total protein, lipid, and energy of fresh eggs all increased proportionately with weight. Comparison of egg composition and standard flight muscle weight of laying females indicated moderate positive, although nonsignificant, correlations between body condition and measures of egg quality, especially lipid content. Based on postegg-laying body composition and nutrient requirements for the production of one egg, it appeared that most females probably could have laid an additional egg almost solely from body reserves. Clutch size thus appears to be independent of body condition. Received 20 June 1985, accepted 16 December 1985.
\end{abstract}

RECENT studies on the evolution of reproductive patterns in birds have emphasized the proximate controls of reproduction, and the bases for phenotypic variation in reproductive traits (Ankney and MacInnes 1978, Drent and Daan 1980, Petrie 1983, Järvinen and Väisänen 1984, Murphy et al. 1984). Because intrapopulation variation in timing of breeding is often considerable, and because of the direct influence of size on energy metabolism (Lasiewski and Dawson 1967, Walsberg 1983), various authors have proposed a dependence of breeding date on body size. Small females presumably can divert a greater portion of daily food intake to reproduction, and are predicted to become reproductively active before large females (Wiley 1974, Downhower 1976). Numerous studies (see Davies and Lundberg 1985) support claims that timing of breeding is often energy limited in birds (Perrins 1970, Yom-Tov and Hilborn 1981). Early breeding is advantageous because

\footnotetext{
${ }^{1}$ Present address: Department of Life Sciences, Indiana State University, Terre Haute, Indiana 47809 USA.
}

it increases the probability of survival of fledged young (Campbell in Lack 1966; Nelson 1966; Perrins 1966, 1970, 1980; Nisbet and Drury 1972; Garnett 1981; Cooke et al. 1984; Newton and Marquiss 1984; Arcese and Smith 1985), raises the potential for rearing multiple broods or laying replacement clutches (Price 1984), and affects clutch size itself in species exhibiting a seasonal drop in clutch size. Examination of the relationship between body size and breeding date thus offers one means of testing for an energetic limit to the start of breeding.

Eastern Kingbirds (Tyrannus tyrannus) annually raise a single brood of 3 or 4 young (Murphy 1983a). In all years clutch size declines seasonally, yet each season initial clutches of different females are laid as much as 5, but usually 4, weeks apart. Egg weight also exhibits wide variability. I have proposed that intrapopulation variation in kingbird egg weight reflects size differences among females and that kingbirds delay breeding to avoid weather-induced food shortages early in the breeding season (Murphy 1983a). Other observations, however, are consistent with the hypothesis that egg production is constrained by insufficient 
resources. These include periods of up to 2 weeks between completion of nest construction and egg-laying, occasional suspension of laying during clutch production (Murphy 1983a), and a direct correlation between egg size and air temperature during the period of egg formation (Murphy 1985).

In the present investigation I test the hypotheses that timing of breeding is energy limited in Eastern Kingbirds, and that egg size variation stems from size differences among females. I also examine the potential for an energy or nutrient limit to clutch size. Tests were made using information on body size and composition of female kingbirds with known reproductive histories, and through examination of egg composition and energy content.

\section{METHODS}

Study area and field methods.-Birds were collected in 1983 from a population in Douglas Co., eastern Kansas, about $6.5 \mathrm{~km}$ west of the city of Lawrence and immediately north of Clinton Reservoir $\left(38^{\circ} 37^{\prime} \mathrm{N}\right.$, $\left.95^{\circ} 19^{\prime} \mathrm{W}\right)$. Methods for locating and monitoring the progress of nesting pairs were identical to those used previously (Murphy 1983a).

I collected 23 breeding females as soon after the end of egg-laying as possible using a .22-caliber rifle and "dust shot." I also collected 5 females that were either migrants or in the process of selecting mates and settling on territories (= prebreeding females). Hour of collection was not standardized, but about $75 \%$ of the females were taken between 0900 and 1500 CST. Among nesting pairs, females were identified by behavior. Of the breeding females taken, 18 were collected 0-2 days after the laying of the last egg, and 1 each 5, 8, 21, and 25 days after the laying of the final egg. One female was collected on the evening before she laid her first egg (she contained one fully shelled egg plus three large yolky follicles). Twenty-five males were collected and analyzed identically. Skeletons were ultimately obtained from each specimen (see below), all of which are located in the Kansas University Museum of Natural History (KUMNH, numbers 80262-80314).

Field measurements of collected birds included body weight, tarsus, wing chord (flattened), and tail lengths, and bill length (anterior edge of nares to tip), width, and depth (both taken at the anterior edge of the nares). I recorded keel length as the average of three measurements of the distance from the base of the sternum to the base of the furcula. Weight was taken to the nearest $0.1 \mathrm{~g}$ with a spring scale, and wing chord and tail were measured to the nearest $0.5 \mathrm{~mm}$ using a $15-\mathrm{cm}$ ruler. The remaining lengths were taken to the nearest $0.1 \mathrm{~mm}$ using dial calipers.
Scales and calipers were checked regularly for accuracy. Birds were then frozen for later body composition analysis.

Carcass analysis. - All laboratory analyses were performed without knowledge of individual female identities until after the completion of the size and composition analyses. A curatorial assistant assigned each specimen a KUMNH number, which I used as an identifier until I completed the laboratory work.

Carcasses were thawed, plucked free of feathers, and then the skin and all visible subcutaneous, mesenteric, and abdominal body fat were removed (= depot body fat), weighed, and refrozen. The pectoral flight muscles (pectoralis, supracoracoideus, and coracobrachialis) were dissected bilaterally and refrozen. Gonads were examined to confirm sex. Flight muscle chord (base of sternum to tip of shoulder) was measured at this time. Small samples of muscle (0.5-1.0 g) from the carcass were removed and refrozen. The remaining carcass, excluding the viscera, was then dried to constant weight at $60^{\circ} \mathrm{C}$ (all oven drying was at this temperature) and weighed to the nearest 0.0001 g. I assumed that visceral fat and protein did not contribute substantially to reproduction and excluded it from all analyses. Clean, air-dried skeletons were obtained following about one month of maceration in water. Skeletons were placed in a desiccator for 24 $\mathrm{h}$ before weighing (nearest $0.0001 \mathrm{~g}$ ). Total skeleton weight and weight of the skull and mandibular elements were recorded.

All dissected muscle samples were oven dried to constant weight and then roughly powdered with mortar and pestle. This was followed by extraction of lipids using petroleum ether in a six-sample Soxhlet apparatus. I dried lipid-free samples to constant weight. The weight difference between dry and lipid-free (= lean) dry samples was the ether-extractable muscle lipid content. The weight difference between the dry skeleton and dry skeleton plus carcass, plus the weight of the small muscle sample, comprised the carcass muscle weight. I used the percentage of lipid in the small sample as an estimate of the percentage of the total quantity of lipid matter in the carcass.

The sum of carcass muscle weight (CMW) and lean, dry pectoral flight muscle weight (FMW) was the total muscle weight (TMW). The quantity of lipids in the pectoral flight muscles and carcass equaled total muscle lipid. I assumed that the proportional weight of skin was the same in all birds, such that differences in skin and depot fat among individuals reflected differences in fat content only. To dry skin and fat I soaked tissues in chloroform-ether (3:1) and then oven dried samples for 2 days. The mean weight of dried skin from 5 individuals with no visible fat stores was $0.704 \mathrm{~g}$ (range: 0.602-0.737). Subtraction of this value from those given in Table 3 permits estimation of the approximate weight of female depot body fat. 


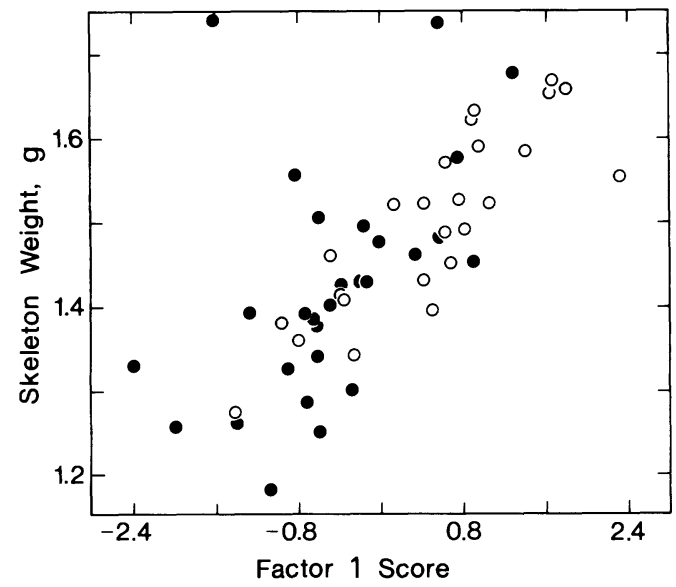

Fig. 1. Skeleton weight (excluding skull and trophic elements) vs. score on factor 1 from the principal components analysis of skeletons for individual female (closed circles, $n=28$ ) and male (open circles, $n=25$ ) kingbirds. Regression equations describing the relationship in the two sexes are: females, $Y=$ $0.075 X+1.446, r^{2}=0.201, P<0.05$; males, $Y=$ $0.098 X+1.449, r^{2}=0.710, P<0.001$.

Egg composition. - Unincubated eggs were available from 21 different females, including 12 of the $23 \mathrm{fe}$ males collected for body composition analysis. Number of eggs analyzed per female varied from 1 to 3 , but in all statistical treatments I used only one observation/female, either the single egg or the average of 2 or 3 eggs. Fresh weights of egg components were determined on the day of collection. I measured weight of the whole egg to the nearest $0.001 \mathrm{~g}$ on a Mettler balance, separated yolk, albumen, and shell (plus membranes) into tared weighing dishes, and then oven dried egg components to constant weight. I calculated total wet albumen weight as the difference between whole egg weight and the combined weights of yolk and dry shell.

Ether-extractable lipid content of yolk and albumen were determined using the six-sample Soxhlet apparatus. I extracted lipids from 6 dry yolks for 45 min, dried and reweighed the samples, and then repeated the procedure. The weights of dry matter remaining at the end of the two analyses were identical. I therefore extracted lipids from the remaining yolks for $45 \mathrm{~min}$. Albumen samples yielded no measurable amounts of ether-extractable lipids.

Based on these measurements and several assumptions (see below), I calculated the absolute quantity and percentage of egg comprised of shell, albumen, and yolk (both dry and wet), water, lipid, protein, and the total energy content. Dry shell weight plus membranes equaled shell weight. Yolk water content was the difference between wet and dry weights. Lipid content of yolk was the difference between pre- and postextraction dry yolk weights. The water content of albumen of Temperate Zone passerines averages about $90 \%$ (Ricklefs 1977, Bancroft 1985). I assumed this to be true of kingbirds, and multiplied total wet albumen weight by 0.10 to obtain dry albumen weight. Because the percentage of fresh kingbird eggs comprised of shell (dry), albumen, and yolk and the percentage of yolk comprised of water and lipids (based on dry weights) were very similar to the eggs of Boat-tailed Grackles (Quiscalus major; Bancroft 1985), I assumed that the percentages of dry yolk and dry albumen made up of protein were also alike. I therefore multiplied dry yolk weights by 0.385 and dry albumen weights by 0.918 (Bancroft 1985) to determine their approximate protein contents. Egg energy content was determined by multiplying the quantity of protein by $23.7 \mathrm{~kJ} / \mathrm{g}$ and the quantity of lipids by $39.6 \mathrm{~kJ} / \mathrm{g}$.

Data analysis. - Measures of body size included FMW, TMW, and linear morphological measurements of size. To obtain relatively unbiased estimates of structural size, I applied separate principal components analyses (PCA) based on correlation matrices (BMDP4M, Dixon 1981) to the lengths of 16 skeletal elements and 7 external morphological features measured on each female and male. Characteristically, factor 1 from a PCA of morphological characters reflects size variation. This was true of kingbirds because all 16 skeletal measurements loaded positively on factor 1 in the first PCA, as did the 7 external morphological characters in the second (Murphy MS). A single numerical estimate of size (factor 1 score) thus was obtained that took all measurements into account.

Females differed considerably in size. For this reason I controlled for covariation of body composition with overall size before testing specific hypotheses. To estimate "protein availability," for example, I followed Fogden and Fogden's (1979) procedure and divided lean, dry FMW by the cube of flight muscle chord (= standardized flight muscle weight, SFMW). I used the difference in weight between the observed and predicted weight of the skeleton (minus the skull and mandibular elements) as an index of "calcium availability." I obtained predicted skeleton weight from the regression equation describing the relationship between skeleton weight and size (= factor 1 score) for males. I assumed that the relationship between skeleton weight and factor 1 score in males was unbiased because males did not have to mobilize calcium for egg formation. This was supported by the fact that female factor 1 scores explained only $20 \%$ $(r=0.447, \mathrm{df}=26, P<0.05)$ of the variation in $\mathrm{fe}-$ male weights, whereas male factor 1 scores explained $71 \%$ of the variation in male skeleton weights $(r=$ 0.842 , df $=23, P<0.001$; Fig. 1). Because neither the slopes nor the $Y$-intercepts for these equations differed significantly between the sexes (Fig. 1), I used the male regression line to predict a female's skele- 
ton weight from her factor 1 score. This value presumably represented the skeleton weight of a female that was not breeding, and I used the difference from predicted skeleton weight (DPSW; observed - predicted) as a relative index to the amount of calcium used or still available for egg production. Other tests utilized multiple linear regression to control for body size differences and are described in the Results at the appropriate sections. I used a probability level of 0.05 as the standard level for accepted statistical significance. Table 1 summarizes all abbreviations used in the text.

\section{RESULTS}

Egg-laying occurred significantly later in 1983 than in previous years due to low ambient temperatures and high rainfall in the early breeding season (Murphy 1985). As in other years, however, clutch size varied between 2 and 4 eggs, and dates for initiation of first clutches differed among females by 4 weeks. Mean egg weight was also statistically indistinguishable from mean weight in any other year in Kansas (Murphy 1985).

\section{TIMING OF BREEDING}

Breeding date did not covary significantly with any of the external measurements of size (weight, $r=0.279$; wing chord length, $r=$ -0.202 ; tarsus length, $r=0.114$; keel length, $r=0.110$ ) or with score on factor 1 from the PCA of external morphological characters $(r=$ 0.335 ). Degrees of freedom were 21 for all analyses except weight, for which the two females collected during the nestling period were excluded. Although timing of breeding (ToB) tended to be later as both weight and factor 1 score increased, as predicted, only $7.8 \%$ and $11.2 \%$ of the variability in breeding date was accounted for, respectively.

On the other hand, factor 1 score from the PCA of the skeletal measurements correlated positively with $\mathrm{ToB}$ and was marginally significant using a two-tailed test $(r=0.402, P=0.06)$. ToB also was correlated positively and significantly with FMW $(r=0.465, P=0.028)$ and TMW $(r=0.507, P=0.014)$, but was not correlated significantly with SFMW $(r=0.252$, $P>0.05 ; \mathrm{df}=21$ for all analyses). Early-breeding females thus tended to be the smallest individuals in the population, whereas the largest individuals bred the latest. Especially noteworthy is that ToB was correlated most
TABLE 1. Abbreviations used in the text.

\begin{tabular}{ll}
\hline $\begin{array}{c}\text { Abbrevi- } \\
\text { ation }\end{array}$ & \multicolumn{1}{c}{ Variable name } \\
\hline CMW & Carcass muscle weight \\
FMW & Flight muscle weight \\
TMW & Total muscle weight \\
SFMW & Standardized flight muscle weight \\
DPSW & Difference from predicted skeleton weight \\
ToB & Timing of breeding \\
FEW & Fresh egg weight \\
\hline
\end{tabular}

highly with TMW, suggesting a direct energetic basis for differences in ToB among females.

Separate analysis of ToB vs. body size for females that laid 2 or 3 vs. 4 eggs indicated that in both groups small females tended to breed the earliest. In the 4-egg category, the relationship between ToB and TMW was significant (Fig. 2; $r=0.870, \mathrm{df}=4, P=0.03$ ), but in the 2/3-egg category, although the relationship was in the predicted direction, it did not attain significance $(r=0.386, \mathrm{df}=15, P=0.132)$. This lack of significance can be attributed to a single large female that laid unusually early (open circle in Fig. 2). Exclusion of this female resulted in a highly significant relationship ( $r=$ $0.581, \mathrm{df}=14, P=0.012$ ). Hence, 4-egg clutch females tended to breed earlier than equal-size females in the 2/3-egg class (Fig. 2), but as indicated by the nearly identical regression coefficients between ToB and TMW (see Fig. 2), increasing size resulted in identical delays in egglaying within the two clutch-size categories.

Multiple regression of ToB against TMW and clutch size produced an increase in the explained variation $\left(R^{2}\right)$ to 0.481 with entry of TMW at step 1 and clutch size at step $2(\mathrm{df}=$ $2,19, P<0.01)$. Exclusion of the single earlybreeding, 3-egg clutch female raised the explained variation in ToB to 0.642 in the twovariable model. Hence, differences in body size explained about $25-40 \%$ of intrapopulational variation in breeding date, while factors associated with clutch size accounted for about an additional $25 \%$.

\section{EGg TRAITS}

Weight.-Using either one- or two-tailed tests, egg weight did not correlate significantly with female weight $(r=-0.063)$, wing chord $(r=$ $0.063)$, tarsometatarsus $(r=0.223)$ or keel 


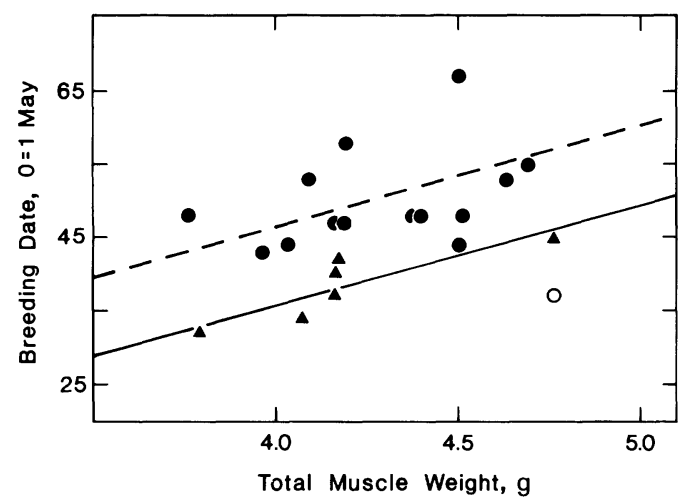

Fig. 2. Breeding date (date on which first egg was laid) plotted against the female's total muscle weight (lipid free and dry) in kingbirds breeding in Kansas in 1983. Triangles represent 4-egg clutch females (CS4) and circles represent 2- or 3-egg clutch females (CS2/3). The regression equation describing the relationship between date and weight for CS4 (solid line) is $Y=13.59 \mathrm{X}-18.51, r^{2}=0.757, P=0.03$ and for CS2/3 (dashed line), $Y=13.94 X-9.13, r^{2}=0.337$, $P=0.01$. The equation for $\mathrm{CS} 2 / 3$ does not include the open circle (see text); with its inclusion, the regression for $\mathrm{CS} 2 / 3$ is $Y=9.76 X-8.00, r^{2}=0.149$, $P=0.132$.

lengths $(r=0.032)$, or factor 1 score from the PCA of either external $(r=0.187)$ or skeletal characters $(r=0.335)$. Based on a one-tailed test, mean egg weight varied significantly with FMW $(r=0.354, P=0.04)$ and TMW $(r=0.373$, $P=0.03)$. However, when the conservative twotailed test was used, egg weight correlated significantly only with SFMW $(r=0.463, P=0.03$, Fig. 3; $\mathrm{df}=21$ for all analyses except weight, for which $\mathrm{df}=19$ ). The correlation between SFMW and egg size remained significant when I restricted the analysis to females collected within two days of the end of egg-laying ( $r=$ $0.516, \mathrm{df}=16, P=0.03$ ).

Correlations based on ratios may give spurious results, however, because of separate correlations between the dependent variable and either the denominator or numerator (Atchley and Anderson 1978). I therefore checked the above results by relating egg weight to residual flight muscle weight, which was obtained as the deviation from the regression of log FMW on log flight muscle chord. Egg weight and residual flight muscle weight were correlated significantly, whether based on the entire sample of females $(r=0.432, P=0.042, \mathrm{df}=21)$ or

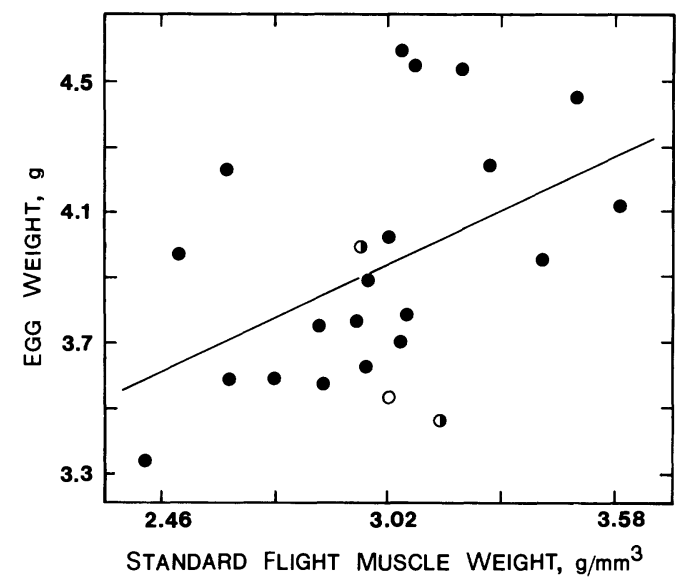

Fig. 3. Mean egg weight in each clutch vs. the female 's standard flight muscle weight (SFMW). The regression equation describing the relationship ( $Y=$ $\left.0.580 X+2.189, r^{2}=0.214, n=23\right)$ is significant $(P=$ 0.03 ). The open circle represents a female collected during egg-laying, and the half-filled circles represent 2 females collected during the nestling period. The actual value of SFMW is times $10^{-5}$.

the restricted set $(r=0.491, P=0.041, \mathrm{df}=16)$. Similar amounts of variation also were explained by the correlations derived by the two techniques. Egg weight appears to be related partially to the relative size of a female's pectoral flight muscles.

Egg composition and female condition. - The wet weight of Eastern Kingbird eggs was comprised of, on average, $5.6 \%$ sheil (dry), $72.5 \%$ albumen, and $21.9 \%$ yolk. The dry weights of the same components were $25.2 \%, 32.4 \%$, and 42.3\% (Table 2). Excluding shell, yolk constituted $23.2 \%$ of wet and $56.6 \%$ of dry egg weight. Eastern Kingbird eggs are thus typical of altricial species (Carey et al. 1980). Given the values in Table 2 and the stated assumptions (see Methods), an average kingbird egg contained $3.08 \mathrm{~g}(77.6 \%)$ of water, $0.409 \mathrm{~g}(10.3 \%)$ of protein, and $0.205 \mathrm{~g} \mathrm{(5.2 \% )}$ of lipid. Using SI conversion units, an average egg contained 17.81 $\mathrm{kJ}$ of energy, or $4.49 \mathrm{~kJ} / \mathrm{g}$ of fresh egg weight (FEW).

Of the dry fractions of yolk, shell, and albumen, only yolk did not vary in direct proportion to FEW (Table 3). The proportion of dry yolk declined as FEW increased $(P<0.05)$. Yolk composition also varied with FEW. The quantity of lipids in yolk (= total lipids in the egg) increased proportionately with FEW, but non- 
TABLE 2. Weights (g) and composition of Eastern Kingbird eggs collected in Kansas during the 1983 breeding season. Sample size (number of females from which eggs were collected) is 21 for all analyses.

\begin{tabular}{lccc}
\hline \hline \multicolumn{1}{c}{ Variable } & Mean & SD & Range \\
\hline Total weight & 3.97 & 0.419 & $3.1-4.8$ \\
Shell weight & 0.224 & 0.023 & $0.176-0.274$ \\
Albumen weight & 2.88 & 0.320 & $2.15-3.67$ \\
Yolk weight & 0.87 & 0.084 & $0.74-1.04$ \\
Yolk/albumen (wet) & 0.303 & 0.031 & $0.234-0.367$ \\
Percent water in yolk & 56.3 & 2.110 & $53.4-61.3$ \\
Dry yolk weight & 0.376 & 0.035 & $0.324-0.445$ \\
Percent lipida & 54.6 & 3.12 & $46.0-63.2$ \\
Percent nonlipida, & 45.4 & 3.12 & $36.8-54.0$ \\
Dry albumen weight & 0.288 & 0.032 & $0.215-0.367$ \\
Yolk/albumen (dry) & 1.32 & 0.117 & $1.06-1.57$ \\
\hline
\end{tabular}

a Percent lipid and percent nonlipid refer to dry yolk.

${ }^{b}$ Nonlipid matter in yolk approximates yolk protein content (Alisauskas and Ankney 1985).

lipid dry matter in yolk $(\approx$ protein; Alisauskas and Ankney 1985) did not (Table 3). Thus, total yolk weight did not increase proportionately as FEW increased because the proportion of protein in yolk failed to vary proportionately with egg weight. Both total protein and lipid increased proportionately with FEW, however, indicating that the energetic cost of producing an egg was directly proportional to FEW (Table $3)$.

In the sample of eggs for which females also were collected, total lipid, total energy ( $\mathrm{kJ})$, lipid-free dry yolk, and total protein varied directly with female SFMW (Fig. 4), but only 7$16 \%$ of the variation in any of the variables was related to SFMW. One nest in particular (39, open ellipses in Fig. 4) eliminated several potentially significant relationships, especially total lipids and energy (Fig. 4a, b). With its exclusion, the amount of variation that could be attributed to SFMW increased to $25-30 \%(P=$
$0.10)$ for lipid-free dry yolk and total protein, but to over $50 \%$ for total lipids $(P=0.01)$ and total energy $(P=0.015)$.

Lipid and calcium use.-Given that total egg lipids increased proportionately with egg size, I predicted that increasing egg size would reduce the total amount of extractable lipids from the pectoral flight muscles, and that within the group of females with egg composition data, pectoral muscle lipid content would decline as egg lipid content increased. I restricted both analyses to females taken within two days of the end of egg-laying $(n=18)$ to minimize potential effects of collection interval on pectoral muscle lipid content. In addition, I predicted that as egg size increased, the store of calcium (DPSW) would decline. Only the egg-laying female was excluded from tests of the latter hypothesis.

Results of the analyses of egg lipids vs. pectoral lipid content were equivocal. Lipid con-

TABLE 3. Power equations of the form $Y=a X^{b}$ describing variation in egg composition $(Y)$ with increasing fresh egg weight $(X)$ in Eastern Kingbirds from 1983 in eastern Kansas. Sample size was 21 and mean egg weight was $3.97 \mathrm{~g}$ for all analyses. Included below are the $Y$-intercept (a), regression coefficient (b), and $95 \%$ confidence interval (CI in parentheses), mean of the dependent variable $(\bar{Y})$ and $95 \%$ confidence interval, and the coefficient of determination $\left(r^{2}\right) .^{\mathrm{a}}$

\begin{tabular}{lllccc}
\hline \hline \multicolumn{1}{c}{ Variable } & $\mathrm{a}$ & \multicolumn{2}{c}{$\mathrm{b}(95 \% \mathrm{CI})$} & $\bar{Y}(95 \% \mathrm{CI})$ & $r^{2}$ \\
\hline Dry shell $(\mathrm{g})$ & 0.076 & $0.783(0.467-1.039)$ & $0.224(0.216-0.229)$ & 0.631 \\
Dry yolk $(\mathrm{g})$ & 0.139 & 0.722 & $(0.551-0.893)$ & $0.376(0.368-0.382)$ & 0.614 \\
Dry albumen $(\mathrm{g})$ & 0.066 & $1.073(0.943-1.203)$ & $0.288(0.282-0.290)$ & 0.940 \\
Total lipids $(\mathrm{g})$ & 0.056 & $0.936(0.527-1.345)$ & $0.205(0.196-0.213)$ & 0.547 \\
Nonlipid yolk $(\mathrm{g})$ & 0.087 & $0.484(-0.075-1.043)$ & $0.170(0.160-0.179)$ & 0.297 \\
Total protein $(\mathrm{g})$ & 0.111 & $0.945(0.815-1.074)$ & $0.409(0.402-0.413)$ & 0.973 \\
Total energy $(\mathrm{kJ})$ & 4.89 & 0.942 & $(0.732-1.152)$ & $17.8(17.38-18.15)$ & 0.822 \\
\hline
\end{tabular}

a All correlations are significant at $P<0.001$ except nonlipid yolk, which is significant at $P=0.01$. 

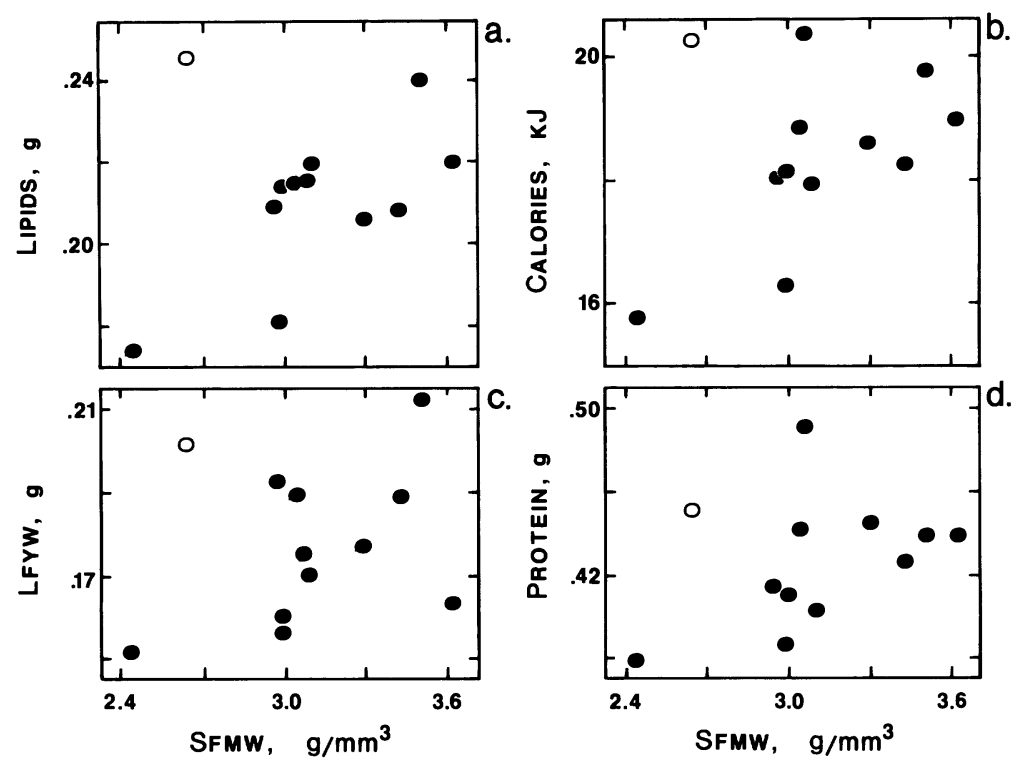

Fig. 4. Egg composition data vs. the standard flight muscle weight (SFMW) of the laying female for 12 individuals collected within two days of the end of egg-laying. The four components presented are (a) total egg lipids (= yolk lipids), (b) total calories, (c) the lipid-free weight of the yolk (LFYW), and (d) total egg protein. Coefficients of determination $\left(r^{2}\right)$ and regression equations were calculated between SFMW and the four variables (log-log transformation) both with and without nest 39 (open ellipses; see text). For each variable, the $r^{2}$ with and without nest 39 is: (a) lipids, $14.4 \%$ and $53.8 \%$, (b) calories, $16.9 \%$ and $50.6 \%$, (c) LFYW, $7.2 \%$ and $26.2 \%$, and (d) protein, $13.6 \%$ and $29.5 \%$. The actual value of SFMW is times $10^{-5}$.

tent of the pectoral muscles did not vary with egg weight $(r=-0.041, \mathrm{df}=16)$. The relationship between egg and pectoral lipid content was also nonsignificant $(r=-0.383$, $\mathrm{df}=12)$, but pectoral lipid content tended to decline as yolk lipid content increased. Correction for collection interval using multiple regression analysis increased the explained variation in pectoral muscle lipids to $0.285(R=0.534)$. The correlation of residual pectoral fat content (effects of collection interval controlled; Fig. 5a) indicated that most of the increase in the multiple coefficient of determination was due to egg lipid weight as it alone accounted for $81.4 \%$ $(r=-0.482)$ of the total explained variation, although again it was not significant $(P>0.05)$.

The relationship of egg size to calcium use (DPSW) exhibited a stronger and much clearer pattern. Egg weight and DPSW were correlated significantly and negatively $(r=-0.432, \mathrm{df}=$ $20, P<0.05)$. A trend also existed for DPSW to decline as eggshell weight increased $(r=$ -0.488 ) in the 12 females for which I had data on both body and egg composition (Fig. $5 b$ ). These patterns suggest strongly that the skeleton was used as a proximal source of calcium during egg formation, and that producing large eggs required the use of relatively greater amounts of endogenous calcium.

\section{Clutch Size}

SFMW exhibited extensive overlap among prebreeding females and females in various stages of breeding. Because SFMW tended to vary with ToB ( $r=0.252$, NS), as did clutch size $(r=-0.591, P<0.01)$, it was necessary to control for differences in breeding date before testing for a relationship between clutch size and SFMW. I accomplished this by comparing the residuals from the regression of SFMW on ToB to clutch size for females laying 2 or 3 vs. 4 eggs. Differences in residual SFMW between females in the two clutch-size categories were not significant $(t=1.24, \mathrm{df}=21, P>0.20)$. Exclusion of the females collected during egg-laying and the nestling period did not alter the results $(t=1.45, \mathrm{df}=18, P>0.10)$.

Lipid and calcium availability also appeared to be independent of clutch size. The quantity of ether-extractable lipids in the flight muscles, in the total muscle mass, and in depot body fat 
did not differ significantly with clutch size (Table 4; two females collected during the nestling period were excluded). Correction for collection interval using multiple regression failed to establish a relationship between clutch size and measures of lipid availability (maximum variation attributable to clutch size was $5 \%$, $\mathrm{df}=2,18$, NS). Although DPSW exhibited a pattern of variation suggesting storage and removal of calcium from bones by egg-laying females (Table 5), breeding category and DPSW were not significantly associated (ANOVA with the egg-laying female excluded, $F=0.72, \mathrm{df}=$ $3,22, P>0.50$ ).

\section{Discussion}

Timing of breeding. - Two main advantages favor early breeding: greater recruitment of young fledged early in the breeding season into the population, and increased opportunity to replace failed clutches or attempt second broods (Downhower 1976, Price 1984). Perrins (1970) suggested that egg-laying dates reflect the outcome of the evolutionary advantages of early breeding and the physiological capability of the female to begin egg-laying. His proposal that timing of breeding is limited by energy availability for females has been supported by the advancement of laying date in 10 of 11 species by experimentally supplementing food supplies (see Davies and Lundberg 1985), by correlations between breeding date and natural variation in food availability (Hogstedt 1974, Greenlaw 1978, Dijkstra et al. 1982, Scott and Birkhead 1983, Murphy 1985), and by correlations between breeding date and male efficiency in provisioning females with food (Nisbet 1977). Others suggest that ToB may not always be limited by energy availability (e.g. Bryant 1975, Smith and Anderson 1982, Turner 1982).

Despite arguments that early reproduction is highly advantageous (e.g. Newton and Marquiss 1984), first-clutch egg-laying dates among seasonally breeding birds usually span a 3-5week period (e.g. Davies and Lundberg 1985, this study; see Bédard and LaPointe 1985 for an exception) or more (Bryant 1975). Except for the almost universal effect of age on breeding date (where older females breed first; Perrins 1970, Crawford 1977, De Steven 1978, and others), the importance of other factors, including body size, is poorly known. Downhower's (1976) energetic model predicted early breed-
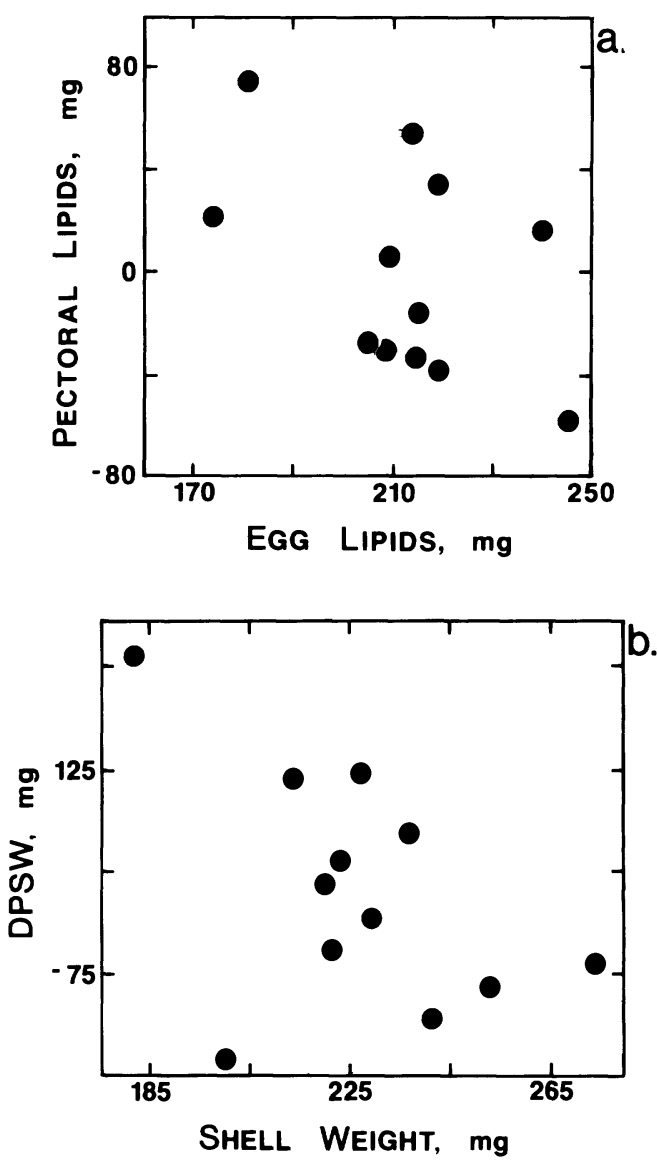

Fig. 5. The relationships between (a) residual lipid content of the pectoral flight muscles (corrected for collection interval) and the lipid content of eggs laid by each female, and (b) the difference from predicted skeleton weight (DPSW) for each female and the weight of the eggshell that she produced. Data are for 12 females collected within two days of the end of egg-laying.

ing in small individuals due to their assumed lower costs for basal (Lasiewski and Dawson 1967) or existence metabolism (Walsberg 1983, Bryant et al. 1985) compared with larger individuals (but see Bryant and Westerterp 1983). Small females presumably expend less time and energy satisfying maintenance requirements, thus enabling them to divert a larger share of daily food intake to reproduction.

The very strong direct correlation between size and timing of breeding in Eastern Kingbirds unambiguously supports the body size/ timing of breeding hypothesis. It is important to note, however, that unless I had examined 
TABLE 4. The quantity of ether-extractable lipids in the flight muscles and total muscle mass, and the total weight of depot body fat ( + skin) in breeding female Eastern Kingbirds in Kansas. Females are grouped according to clutch size: 2 or 3 eggs (CS2/3) vs. 4 eggs (CS4). The value of the Student's $t$-test ( $t$ ) used to compare the two groups is also given.

\begin{tabular}{cccc}
\hline \hline Variable & CS2/3 & CS4 & $t$ \\
\hline Flight muscle & & \\
Mean (SD, $n)$ & $159.2(35.56,16)$ & $151.5(35.49,5)$ & 0.43 \\
Range & $116-262$ & $126-209$ & \\
Total muscle & & & \\
Mean (SD, $n)$ & $422.2(79.42,16)$ & $425.7(94.50,5)$ & $307-545$ \\
Range & $289-571$ & & 0.08 \\
Depot body fat & & $1.35(0.301,5)$ & 0.88 \\
Mean (SD, $n)$ & $1.50(0.344,16)$ & $0.91-1.71$ & \\
Range & $1.04-2.25$ & & \\
\hline
\end{tabular}

a Flight muscle lipids (mg) refers specifically to those in the pectoralis, supracoracoideus, and coracobrachialis muscles.

b Total intramuscular lipids (mg) include the lipids from the flight muscles.

' The weight of dry skin from 5 females with no visible fat stores was $0.704 \mathrm{mg}$ (range: 0.602-0.737). Subtraction of this value from the mean depot lipid value gives the approximate lipid weight $(\mathrm{g})$.

the skeletal material and muscle weights, I would have concluded erroneously that body size had at most a weak influence on breeding date. Instead, the strength of the relationship between size and date increased through the progression from skeletal factor 1 scores $(P=$ $0.06)$ that measure structural size, to TMW $(P=$ 0.014 ), a direct measure of muscle mass. This indicates that reproductive timing was correlated most strongly with the weight of the most metabolically demanding tissue. Hence, failures to detect a relationship between body size and breeding date where only weight or external morphological characters are used as measures of size (e.g. Järvinen and Väisänen 1984) must be interpreted cautiously.

Total muscle weight accounted for $25-38 \%$ of intrapopulation variation in breeding date in Eastern Kingbirds. Hails and Turner (1985) demonstrated that energy in the form of lipids limited the start of breeding in White-bellied Swiftlets (Collocalia esculenta). Conversely, in numerous species protein availability is critical for reproductive timing (Ward 1969, Jones and Ward 1976, Fogden and Fogden 1979, Alisauskas and Ankney 1985). The strong correlation of breeding date with size in Eastern Kingbirds suggests that energy, not protein availability, is the limiting factor.

Price (1984) also detected a greater likelihood of earlier (and longer) breeding in small female Geospiza fortis, but only during certain periods of low food availability. Loman (1984), on the other hand, reported an inverse relationship between female body weight and breeding date in Carrion Crows (Corvus corone). Large species like the Carrion Crow (about 400 g) presumably are capable of storing resources for reproduction (Downhower 1976). Small species probably cannot, however, because of space limitations. Hence, the opposite patterns detected by Price (1984) and in my study compared with Loman (1984) probably are related to differences in body size of the study species.

In Common Moorhens (Gallinula chloropus) small males apparently are preferred as mates because their metabolic demands are less than large males, and as a consequence they are more

TABLE 5. The difference in observed female skeleton weight from that predicted from the factor 1 score and the regression equation describing the relationship between factor 1 score and skeleton weight in males (DPSW). See Methods and Fig. 1 for a detailed explanation of methods. Categories include prebreeding females, laying females, and breeding females that laid 2, 3, or 4 eggs. Values are in $\mathrm{mg}$.

\begin{tabular}{lrcr}
\hline \hline $\begin{array}{c}\text { Breeding } \\
\text { category }\end{array}$ & Mean & SD $(n)$ & \multicolumn{1}{c}{ Range } \\
\hline $\begin{array}{c}\text { Prebreeding } \\
\quad \text { females }\end{array}$ & 47.8 & $82.40(5)$ & -49 to 117 \\
$\begin{array}{l}\text { Laying females } \\
\text { Clutch size }\end{array}$ & 450.0 & $-(1)$ & - \\
2 eggs & & & \\
3 eggs & 84.0 & $43.84(2)$ & 53 to 115 \\
4 eggs & -2.7 & $112.12(15)$ & -165 to 229 \\
& -5.3 & $78.47(5)$ & -87 to 119 \\
\hline
\end{tabular}


TABLE 6. Comparison of females that laid 2 or 3 eggs $(C S 2 / 3, n=17)$ with those that laid $4(C S 4, n=6)$. Values are presented as mean (SD).

\begin{tabular}{lcccc}
\hline \hline Variable & CS2/3 & CS4 & $t$ & $P$ \\
\hline Wing chord (mm) & $110.0(1.644)$ & $112.8(2.788)$ & 2.98 & $<0.01$ \\
Keel (mm) & $26.01(1.225)$ & $26.83(0.742)$ & 1.49 & NS \\
Tarsus (mm) & $19.44(0.666)$ & $19.57(0.780)$ & 0.39 & NS \\
Weight (g) & $42.0(2.504)$ & $42.1(2.741)$ & 0.08 & NS \\
Factor 1 (skeleton) & $-0.392(0.6147)$ & $-0.368(0.7408)$ & 0.08 & NS \\
\hline
\end{tabular}

attentive during incubation (Petrie 1983). In this species only males incubate. Females mated to small males also initiated more clutches per year (Petrie 1983). This observation suggests an energetic advantage to small size during breeding, which for the females of most passerines should produce a reproductive advantage (assuming that early breeding is advantageous). The usual pattern of sexual size dimorphism in birds of males larger than females may be at least partly the result of "fertility" selection (Price 1984) for small size in females (Wiley 1974, Downhower 1976). Presumably, factors act at other points in the life cycle to balance selection for small size such that intersexual differences in body size remain stable (e.g. Perrins 1980).

In addition to body size, some factor associated with the laying of different-size clutches explained about an additional $25 \%$ of the variation in breeding date. A comparison of the morphology of females laying 2 or 3 vs. 4 eggs (Table 6) implied it was an age effect. None of the measures of size differed between females in the two groups, except that females that laid 4 eggs had significantly longer wing chords. In general, wing chord length increases with age in passerines (Alatalo et al. 1984, Bédard and LaPointe 1985), as does clutch size. Hence, it is highly probable that older female kingbirds bred first, and that age and body size together accounted for at least $50 \%$, and possibly as much as $65 \%$, of intrapopulation variation in breeding date.

Egg and clutch size.-My results do not support the hypothesis that egg weight varies due to differences in female body size. None of the structural measures of size correlated significantly with egg weight, and of the muscle weights only SFMW explained a significant portion of egg weight variation. Although this accounted for only $21-25 \%$ of the observed variability, it does suggest that egg weight in kingbirds was more a matter of body condition than size, assuming that SFMW reflects body condition. This concurs with findings that annual variation in egg weight correlates directly with food availability (Murphy 1985).

Females in good condition thus tend to lay large, high-quality eggs. The pattern of increasing egg weight (Fig. 3) and egg lipid (Fig. 4) with SFMW, decreasing pectoral lipids with increasing egg lipids (Fig. 5a), and decreasing DPSW with increasing shell weight (Fig. 5b) suggests that either lipid or calcium availability limits egg size. Nonetheless, total protein requirements for egg production may also limit egg size as protein requirements were twice those for lipids (Tables 2 and 3). Protein is very important in egg formation in a wide range of birds (Robbins 1981, Sharp and Moss 1981, Astheimer 1985). I doubt that protein is limiting for kingbirds, however, because during the breeding season they are almost entirely insectivorous, and insects are rich in protein (Turner 1982). Although the pectoral flight muscles may be a source of and storage site for protein or specific amino acids (Kendall et al. 1973), the direct correlation between total egg lipids and SFMW suggests that the pectoral muscles are the site for short-term storage of the endogenous lipids used in egg production. The fact that insects contain few lipids (Turner 1982) lends credence to this hypothesis. Insects are also low in calcium (Turner 1982). However, I regularly obtained small snails in insect sweep samples in kingbird foraging habitats (Murphy 1985). Selective foraging on molluscs may provide calcium for eggshell formation.

I found no evidence that the number of eggs produced is limited by resource limitation. I am unable to assess directly whether females store and deplete resources during clutch production (e.g. Jones and Ward 1976, Hails and Turner 1985). Yet, based on a knowledge of egg composition (Table 2) and the body composition of post-egg-laying females (Tables 4 and 5 ), it appears that many females that laid fewer 
than 4 eggs could have laid an additional egg almost solely from endogenous reserves. For example, about $186 \mathrm{mg}$ of calcium were required for eggshell formation (20.9\% of total dry egg weight in Bank Swallows, Riparia riparia; Turner 1982). An average egg also contained $205 \mathrm{mg}$ of lipid and $409 \mathrm{mg}$ of protein (Table 2). Most females carried at least $1.0 \mathrm{~g}$ of lipid (Table 4), and differences in FMW and DPSW among females with 2 or 3 eggs were as much as $490 \mathrm{mg}$ and $394 \mathrm{mg}$ (Table 5), respectively. Certainly, not all lipids were available for use in producing eggs, nor did differences in FMW or DPSW solely represent excess nutrients. By the same token, females of most passerine species, including kingbirds, probably do not produce eggs exclusively from their body stores (Ankney and Scott 1980). Energy and nutrients from stored reserves and daily intake were therefore very likely sufficient to allow a continuation of egg-laying. Other observa. tions, including the laying of the largest clutches during the seasonal low in food availability (Murphy 1983a) and the very weak influence of yearly variation in food abundance on clutch size (Murphy 1985), suggest that clutch size is not energy or nutrient limited in Eastern Kingbirds. Instead, as Davies and Lundberg (1985) generalized for small passerines, factors related to the rearing of young are most likely responsible for the evolution of clutch-size patterns in kingbirds (Murphy 1983a, b, 1985).

\section{ACKNOWLEDGMENTS}

I thank Marion Jenkinson for allowing me to prepare the skeletons as part of my duties as curatorial assistant at the KUMNH, and Dr. Ken Armitage for providing space in his lab and materials for the lipid extractions. Financial support during the summer of 1983 was provided by a Kansas University Graduate School Summer Fellowship. NSF grant BSR 830065 to Dr. George S. Bakken of Indiana State University provided funds during the final analysis and writing of this manuscript. I thank Trevor Price and an anon ymous reviewer for their critical comments. To all I am deeply indebted.

\section{Literature Cited}

$\rightarrow$ Alatalo, R. V., L. Gustafsson, \& A. Lundberg. 1984. Why do young passerine birds have shorter wings than older birds? Ibis 126: 410-415.

$\rightarrow$ Alisauskas, R. T., \& C. D. ANkNey. 1985. Nutrien reserves and the energetics of reproduction in American Coots. Auk 102: 133-144.
ANKNEY, C. D., \& C. D. MACINNES. 1978. Nutrient reserves and reproductive performance of female Lesser Snow Geese. Auk 95: 459-471.

$-\rightarrow-$, \& D. M. ScotT. 1980. Changes in nutrient reserves and diet of breeding Brown-headed Cowbirds. Auk 97: 684-696.

ARCESE, P., \& J. N. M. SMITH. 1985. Phenotypic correlates and ecological consequences of dominance in Song Sparrows. J. Anim. Ecol. 54: 817830.

AstheIMER, L. B. 1985. Long laying intervals: a possible mechanism and its implications. Auk 102: 401-409.

Atchley, W. R., \& D. ANDERson. 1978. Ratios and the statistical analysis of biological data. Syst. Zool. 27: 71-78.

BANCROFT, G. T. 1985. Nutrient content of eggs and the energetics of clutch formation in the Boattailed Grackle. Auk 102: 43-48.

BÉDARD, J., \& G. LAPOINTE. 1985. Influence of parental age and season on Savannah Sparrow reproductive success. Condor 87: 106-110.

BRYANT, D. M. 1975. Breeding biology of House Martins Delichon urbica in relation to aerial insect abundance. Ibis 117: 180-216.

- C. J. HaIls, \& R. PRYS-Jones. 1985. Energy expenditure by free-living Dippers (Cinclus cinclus) in winter. Condor 87: 177-186.

- \& K. R. WESTERTERP. 1983. Short-term variability in energy turnover by breeding House Martins Delichon urbica: a study using doublylabelled water $\left(\mathrm{D}_{2}{ }^{18} \mathrm{O}\right)$. J. Anim. Ecol. 52: 525543.

CAREY, C., H. RAHN, \& P. PARISI. 1980. Calories, water, lipid and yolk in avian eggs. Condor 82: 335-343.

$\rightarrow$ COOKE, F., C. S. Findlay, \& R. F. RockWEll. 1984. Recruitment and the timing of reproduction in Lesser Snow Geese (Chen caerulescens caerulescens). Auk 101: 451-458.

CRAWFORD, R. D. 1977. Breeding biology of yearold and older female Red-winged and Yellowheaded blackbirds. Wilson Bull. 89: 73-80.

DAvies, N. B., \& A. LundBERG. 1985 . The influence of food on time budgets and timing of breeding of the Dunnock Prunella modularis. Ibis 127: 100110.

DE StEVEN, D. 1978. The influence of age on the breeding biology of the Tree Swallow Iridoprocne bicolor. Ibis 120: 516-523.

$\rightarrow$ Dijkstra, C., L. Vuursteen, S. DAAN, \& D. Masman. 1982. Clutch size and laying date in the Kestrel Falco tinnunculus: effect of supplementary food. Ibis 124: 210-213.

DixON, W. J. 1981. BMDP statistical software. Los Angeles, Univ. California Press.

Downhower, J. F. 1976. Darwin's finches and the evolution of sexual dimorphism in body size. Nature 263: 558-563. 
DRENT, R. H., \& S. DAAN. 1980. The prudent parent: energetic adjustments in avian breeding. Ardea 68: 225-252.

Fogden, M. P. L., \& P. M. Fogden. 1979. The role of fat and protein in the annual cycle of the Greybacked Camaroptera in Uganda (Aves: Sylvidae). J. Zool., London 189: 233-258.

$\rightarrow$ GARNETT, M. C. 1981. Body size, its heritability and influence on juvenile survival among Great Tits, Parus major. Ibis 123: 31-41.

GREENLAW, J. S. 1978. The relation of breeding schedule and clutch size to food supply in the Rufous-sided Towhee. Condor 80: 24-33.

$\rightarrow$ Hails, C. J., \& A. K. TuRner. 1985. The role of fat and protein during breeding in the White-bellied Swiftlet (Collocalia esculenta). J. Zool., London 206: 469-484.

Hogstedt, G. 1974. Length of the pre-laying interval in the Lapwing Vanellus vanellus $\mathrm{L}$. in relation to its food resources. Ornis Scandinavica 5: 1-4.

JÄRVINEN, A., \& R. A. VÄISÄNEN. 1984. Reproduction of Pied Flycatchers (Ficedula hypoleuca) in good and bad breeding seasons in a northern marginal area. Auk 101: 439-450.

$\rightarrow$ JONES, P. J., \& P. WARD. 1976. The level of reserve protein as the proximate factor controlling the timing of breeding and clutch-size in the Redbilled Quelea Quelea quelea. Ibis 118: 547-574.

$\rightarrow$ Kendall, M. D., P. WARD, \& S. Bacchus. 1973. A $\rightarrow$ protein reserve in the Pectoralis major flight muscle of Quelea quelea. Ibis 115: 600-601.

LACK, D. 1966. Population studies of birds. Oxford $\rightarrow$ Clarendon Press.

LASIEWSKI, R. C., \& W. R. DAwson. 1967. A re-examination of the relation between standard metabolic rate and body weight in birds. Condor 69 : 13-23.

LOMAN, J. 1984. Breeding success in relation to parent size and experience in a population of the Hooded Crow. Ornis Scandinavica 15: 183-187.

$\rightarrow$ Murphy, E. C., R. H. DAy, K. L. OAKLEY, \& A. A. HOOver. 1984. Dietary changes and poor reproductive performance in Glaucous-winged Gulls. Auk 101: 532-541.

MURPHY, M. T. 1983a. Ecological aspects of the reproductive biology of Eastern Kingbirds: geographic comparisons. Ecology 64: 914-928.

$\rightarrow-$ 1983b. Clutch size in the Eastern Kingbird: factors affecting nestling survival. Auk 100:326334.

—. 1985. Ecological and evolutionary aspects of the reproductive biology of Eastern Kingbirds: annual, seasonal and geographic variation and interspecific differences. Unpublished Ph.D. dissertation, Lawrence, Univ. Kansas.
Newton, I., \& M. Marquiss. 1984. Seasonal trend in the breeding performance of Sparrowhawks. J. Anim. Ecol. 53: 809-829.

Nisbet, I. C. T. 1977. Courtship-feeding and clutch size in Common Terns Sterna hirundo. Pp. 101110 in Evolutionary ecology (B. Stonehouse and C. Perrins, Eds.). Baltimore, University Park Press.

$-\rightarrow-$, \& W. H. DruRY. 1972. Post-fledging survival in Herring Gulls in relation to brood-size and date of hatching. Bird-Banding 43: 161-172.

Perrins, C. 1966. Survival of young Manx Shearwaters Puffinus puffinus in relation to their presumed date of hatching. Ibis 108: 132-135. $\rightarrow$ 1970. The timing of birds' breeding seasons. Ibis 112: 242-255.

1980. Survival of young Great Tits, Parus major. Proc. 17th Intern. Ornithol. Congr.: 159174.

PetriE, M. 1983. Female Moorhens compete for small fat males. Science 220: 413-415.

PRICE, T. D. 1984. The evolution of sexual size dimorphism in Darwin's finches. Amer. Natur. 123: 500-518.

RICKLEFS, R. E. 1977. Composition of eggs of several bird species. Auk 94: 350-356.

RoBbins, C. T. 1981. Estimation of the relative protein cost of reproduction in birds. Condor 83 : 177-179.

ScotT, D. K., \& M. E. BIRKHEAD. 1983. Resources and reproductive performance in Mute Swans Cygnus olor. J. Zool., London 200: 539-547.

SHARP, P. J., \& R. Moss. 1981. A comparison of the responses of captive Willow Ptarmigan (Lagopus lagopus lagopus), Red Grouse (Lagopus lagopus scot$i c u s$ ), and hybrids to increasing daylengths with observations on the modifying effects of nutrition and crowding in Red Grouse. Gen. Comp. Endocrinol. 45: 181-188.

SMith, K. G., \& D. C. ANDERSON. 1982. Food, predation and reproductive ecology of the Darkeyed Junco in northern Utah. Auk 99: 650-661.

TURNER, A. K. 1982. Timing of laying by swallows (Hirundo rustica) and Sand Martins (Riparia riparia). J. Anim. Ecol. 51: 29-46.

WALSBERG, G. E. 1983. Avian ecological energetics. Pp. 161-220 in Avian biology, vol. 7 (D. S. Farner, J. R. King, and K. C. Parkes, Eds.). New York, Academic Press.

WARD, P. 1969. The annual cycle of the Yellowvented Bulbul Pycnonotus goiavier in a humid equatorial environment. J. Zool., London 157: 2545.

WILEY, R. H. 1974. Evolution of social organization and life history patterns among grouse. Quart. Rev. Biol. 49: 201-227.

Nelson, J. B. 1966. The breeding biology of th $\rightarrow$ YOM-Tov, Y., \& R. HilboRn. 1981. Energetic conGannett, Sula bassana, on the Bass Rock, Scotland. Ibis 108: 584-626. straints on clutch size and time of breeding in Temperate Zone birds. Oecologia 48: 234-243. 